J. clin. Path., 25, Suppl. (Roy. Coll. Path.), 6, 34-38

\title{
Cytomegalovirus: a cause of persistent latent infection
}

\author{
H. STERN
}

From St George's Hospital Medical School, London

Although cytomegalovirus has been known for almost 70 years, mainly from the characteristic cytomegalic cells that are found in infected tissues, it was not isolated until 1956. Since then it has become increasingly evident that it possesses a peculiar epidemiology and pathogenesis.

Cytomegalovirus is a member of the Herpesvirus group and like other herpesviruses it causes persistent latent infections. Infection is widespread but occurs predominantly in early infancy and early adult life. In London, for example, about $10 \%$ of infants have acquired cytomegalovirus complement-fixing antibodies by 2 years of age (Fig. 1) (Stern and Elek, 1965). This is followed by a relatively slow rise in the incidence of antibodies, between 2 and 15 years of age, to about $20 \%$. The daily close contacts between children afforded by school life appears to be much less effective for spread of cytomegalovirus than for many other virus infections. After 15 years there is again a rapid increase in antibody incidence to a maximum of 50 to $60 \%$ by $25-30$ years of age. About a third of the population, therefore, becomes infected during the main childbearing period. Similar findings have been reported from other

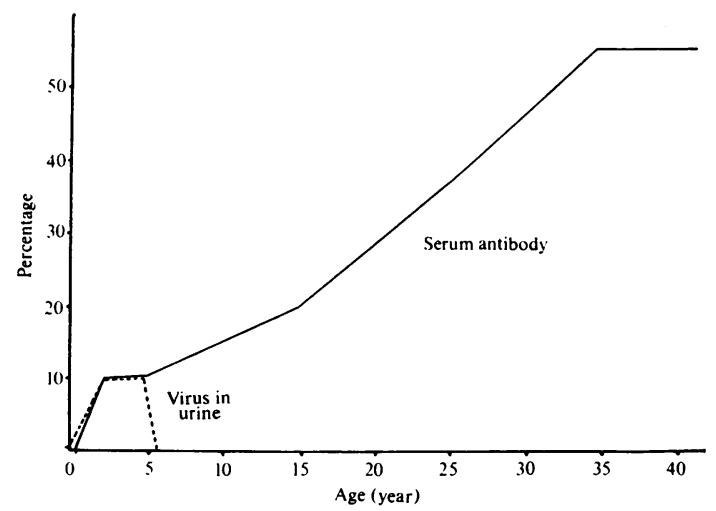

Fig. Incidence of cytomegalovirus complement-fixing antibodies and of cytomegaloviruria in the general population of London. countries of Europe, from the United States, and from Australia (Carlström, 1965; Hanshaw, 1966; Jack and McAuliffe, 1968). However, the prevalence of infection, particularly in early life, is higher in populations living under more crowded and less hygienic conditions. Thus, in the largely Negro population of Washington, DC, and in Puerto Rico $25-35 \%$ of children have antibodies, as do $70-80 \%$ of adults (Rowe, Hartley, Waterman, Turner and Huebner, 1956; Mendez-Cashion, Valcarcel, Ramirez de Arellano, and Rowe, 1963). In London, $60 \%$ of white women attending antenatal clinics have antibodies, as compared with $90 \%$ of immigrant Pakistani women (Stern, 1971).

The infections of early childhood start very early, probably as soon as maternal antibody levels in the infants begin to wane. This is demonstrable by means of virus isolation (Fig.). In Britain, 0.5-1.0\% of newborn babies excrete cytomegalovirus but by 6 months of age the incidence of excretion is $5-10 \%$ (Stern, 1968; Walker and Tobin, 1970). In Far Eastern countries, as well as in Finland, the incidence of excretion in early infancy has been reported to reach as high as 30-60\% (Alexander, 1967; Numazaki, Yano, Morizuka, Takai, and Ishida, 1970; Olson, Ketusinha, Mansuwan, and Snitbhan, 1970; Leinniki, Heinonen, and Pettay, 1971). These infections of early childhood are followed by persistent and prolonged excretion of virus in the throat and urine, lasting commonly for two or three years or more. Congenital infections also result in long-term excretion of virus (Weller and Hanshaw, 1962). On the other hand, virus can be isolated from fewer than $1 \%$ of older children and adults in the general population, even during adolescence and early adult life when, as shown by antibody studies, cytomegalovirus infection is most common (Stern, 1968). Obviously, most primary cytomegalovirus infections in older children and adults occur without, or more probably with only transient, excretion of virus in the throat and urine.

It is not known why infants and young children deal less efficiently with cytomegalovirus infection than their elders. Prolonged excretion of virus 
occurs in them despite often high levels of circulating neutralizing antibody. Cytomegaloviruses are unusually resistant to interferon and are also poor inducers of interferon in vitro (Osborn and Medearis, 1966; Glasgow, Hanshaw, Merigan, and Petralli, 1967). However, this cannot be the whole explanation, especially as children who are chronic excretors of cytomegalovirus show normal interferon responses to challenge with other viruses (Glasgow et al, 1967). Cell-mediated immunity mechanisms are probably more important for the final eradication of virusinfected cells in the body and these mechanisms may still be immature or are perhaps more easily damaged in early childhood. Certainly when primary infection occurs in adults undergoing intensive immunosuppressive therapy for leukaemia or Hodgkin's disease or for organ transplantation they too excrete virus for prolonged periods of time (Duvall, Casazza, Grimley, Carbone, and Rowe, 1966; Kanich and Craighead, 1966). Prolonged excretion also occurs in otherwise healthy women who have experienced primary infection during pregnancy and have given birth to infants with neonatal cytomegalic inclusion disease (Medearis, 1964). Physiological immunosuppression due to increased steroid levels may be the reason here.

The methods of spread of cytomegalovirus infection are still poorly understood. In individuals with active infection virus is excreted into the throat and urine, onto the cervix in women, and in pregnant women even in the milk (Alexander, 1967; Diosi, Babusceac, Nevinglovschi, and Kun-Stoicu, 1967). However, the relatively slow spread of infection among schoolchildren indicates that the virus is not highly contagious by the ordinary respiratory droplet route, perhaps because of its known lability outside the body. That spread can occur by this route and perhaps also by the urine-hands-oral route is shown by studies of children kept under close living conditions. In boarding schools and orphanages as many as $\mathbf{5 0 - 8 0 \%}$ of children may have cytomegalovirus antibodies, compared with only $15-20 \%$ of children of the same ages attending day schools (Stern and Elek, 1965). Efficient cross-infection probably requires direct contact, and the prevalence of infection in adolescents and young adults suggests that cytomegalovirus infection is essentially a 'kissing disease', similar to infectious mononucleosis. Excretion of cytomegalovirus on the cervix makes sexual intercourse a further possible method of spread. This is well established for herpes simplex, but cytomegalovirus has not yet been isolated from the male genital tract. Nevertheless, the significantly greater frequency of congenital infection in babies born to very young unwed mothers than to married women in general (Starr, Bart, and Gold, 1970;
Walker and Tobin, 1970) is indirect evidence for the importance of sexual contact, whether kissing or intercourse, for transfer of infection; the former women are likely to have been more promiscuous than older married women and would thus have been exposed to a greater risk of infection.

Another important method spread is by blood transfusion (Kääriäinen, Klemola, and Paloheimo, 1966). Cytomegalovirus can be isolated from the white blood cells of patients with active infection, including cases of neonatal cytomegalic inclusion disease, adults with cytomegalovirus mononucleosis, and patients undergoing immunosuppressive treatment for leukaemia (Stulberg, Zuelzer, Page, Taylor, and Brough, 1966; Harnden, Elsdale, Young, and Ross, 1967; Lang, Scolnick, and Willerson, 1968). In all these, the virus persists in the blood cells, protected from serum antibody, for many weeks or months. Similar infection of leucocytes occurs in the subclinical infections of otherwise healthy adults; virus has been isolated from $5 \%$ of blood donors, who may carry the virus in the blood without demonstrable excretion in the urine (Diosi, Moldovan, and Tomescu, 1969). How long this latent blood carriage lasts in healthy persons, whether for life or for a shorter period, is unknown, but the presence of virus in the blood of some donors accounts for the occurrence of most cases of the socalled 'postperfusion syndrome'. Indeed, in openheart operations, which require large amounts of fresh blood from multiple donors, as many as $60 \%$ of patients without cytomegalovirus antibodies before operation acquire them after the operation (Paloheimo, von Essen, Klemola, Kääriäinen, and Siltanen, 1968). In other kinds of operations, needing the more usual 1-3 pints of blood, the frequency of primary infection is $5-10 \%$ (Stern, unpublished). The risk of infection is greatest with fresh blood, because of the lability of the virus, but infection can occur also with blood stored for 24 to 48 hours (Stevens, Barker, Ketcham, and Meyer, 1970; Prince, Szmuness, Millian, and David, 1971). The foetus and the newborn baby can be infected similarly by exhange transfusions for blood group incompatibility (King-Lewis and Gardner, 1969; Luthardt, Siebert, Lösel, Quevedo, and Todt, 1971).

Cytomegalovirus, like other herpesviruses, persists in the body as a latent infection. Whether well persons carrying such latent infection experience recurrent reactivations, such as occur with herpes simplex, is as yet unknown. Such reactivations could, of course, play an important part in the spread of infection. The chance of isolating cytomegalovirus from the throat or urine of healthy older children or adults is less than $1 \%$ (Stern, 1968). It may be somewhat higher in the case of the cervix. In a study of 108 unselected 
women admitted to the gynaecological wards of $\mathrm{Si}$ George's Hospital for generally minor illnesses, cytomegalovirus was isolated from the cervix of two out of $39(5 \%)$ women aged 15-30 years, but from nine of 69 women aged 30-65 years. One of the cervix excretors also had virus in the throat but no urine excretors were found. Both excretors possessed complement-fixing antibody when first examined and both had also cytomegalovirus IgM antibody, indicating that they were probably undergoing primary infections. Cervical excretion in young women has also been reported by Walker and Tobin (1970) in Manchester. There is, therefore, little evidence for reactivation in the general population, but this undoubtedly occurs in pregnancy.

In London, primary cytomegalovirus infection affects $1-2 \%$ of pregnant women; about half of these women excrete virus in the urine and give birth to congenitally infected infants (Stern, 1971). A similar proportion of women excrete cytomegalovirus during pregnancy but they already have antibody before the onset of pregnancy and show no significant rise in titre subsequently; they produce healthy babies who are not infected with cytomegalovirus. These are undoubtedly examples of reactivation of latent infection, the preexisting antibody protecting the foetus from intrauterine infection. The frequency of reactivation in London was found to vary from $0.7 \%$ in white pregnant women to $2.9 \%$ in immigrant Pakistani women. This is in accord with the amount of latent infection in the two populations, since $60 \%$ of white women attending antenatal clinics have antibodies as compared with $90 \%$ of the immigrant women. Several groups of workers in Europe and the United States have confirmed that 2-3\% of pregnant women excrete cytomegalovirus in the urine and on the cervix, without any infection of the foetus (Shinefield and Eichenwald, 1968; Hildebrandt, Sever, Margileth, and Callagan, 1967; Krech, Jung, Bärlocher, and Sege, 1968; Feldman, 1969; McCracken, Shinefield, Cobb, Rausen, Dische, and Eichenwald, 1969; Foy, Kenny, Wentworth, Johnson, and Grayston, 1970). In Japan and Taiwan as many as $18-20 \%$ of pregnant women excrete virus on the cervix (Alexander, 1967; Numazaki et al, 1970). Women undergoing reactivation of latent cytomegalovirus infection continue to excrete virus for some time after term, and its presence in the throat and in the milk probably provides the main source of early postnatal infection; most infections of early childhood occur within the first three to nine months of life, soon after the loss of passively transferred maternal antibody (Alexander, 1967; Stern, 1968; Levinsohn, Foy, Kenny, Wentworth, and Grayston, 1969; Walker and Tobin, 1970; Numazaki et al, 1970). It is perhaps significant that the presence of cytomegalic cells in the parotid glands has been reported almost exclusively in infants aged 2-7 months, coinciding with the period of breast feeding (Diosi et al, 1967; Ten Bensel and St Geme, 1968).

Reactivation of latent infection in pregnancy may be due to the increased steroid levels of pregnancy. A more potent method of reactivating all kinds of latent infection, including that of cytomegalovirus, is the intensive immunosuppressive therapy now used for leukaemia and Hodgkin's disease and for kidney and liver transplantation. Fifty to $60 \%$ or more of all patients undergoing such treatment excrete cytomegalovirus in the throat and urine and at necropsy show cytomegalic cell formation, particularly in the lungs but sometimes generalized (Sullivan, Hanshaw, Cangir, and Butler, 1968; Craighead, 1969; Murray-Lyon, Evans, Foster, Holden, Rake, Stern, Calne, and Williams, 1970). Most of them have antibody before the start of treatment, and reactivation usually occurs during the second month. Antibody titres rise and often reach very high levels which may be maintained until the time of death. Some patients, of course, particularly children, are without antibodies before treatment and they may undergo primary infections, either from frequent blood transfusions or perhaps by contact with other patients excreting virus in treatment clinics or hospital wards. Reactivation of latent infection may, in fact, be more common than is realized in debilitating diseases, even apart from immunosuppressive therapy. Craighead (1971) has isolated cytomegalovirus from the lungs of $12 \%$ of unselected adults who had died of various diseases; histological examination usually failed to find cytomegalic cells.

Cytomegalovirus has relatively low pathogenicity for man (Table). The great majority of acquired infections are asymptomatic. Only rarely does illness occur, taking the form of a Paul-Bunnell-negative infectious mononucleosis (Klemola, von Essen, Wager, Haltia, Koivuniemi, and Salmi, 1969). Even when infection is by the intravenous route,

\begin{tabular}{ll}
\hline Group & Illness \\
\hline$>5 \mathrm{yr}$ & $\begin{array}{l}\text { Paul-Bunnell-negative infectious mononucleosis } \\
\text { Postperfusion syndrome } \\
\text { Disturbances of liver function } \\
\text { ? respiratory illnesses }\end{array}$ \\
$\begin{array}{l}\text { Intrauterine } \\
\text { infections }\end{array}$ & $\begin{array}{l}\text { Neonatal cytomegalic inclusion disease } \\
\text { Incomplete neonatal syndrome } \\
\text { Mental retardation and microcephaly } \\
\text { pregnant women }\end{array}$ \\
$\begin{array}{l}\text { Patients on } \\
\text { immuno- }\end{array}$ & $\begin{array}{l}\text { ? small for dates babies } \\
\text { suppressive }\end{array}$ \\
therapy &
\end{tabular}

Table Illnesses associated with cytomegalovirus infection 
that is by blood transfusion, only a few of the resulting primary infections, perhaps $10 \%$ of them, lead to the 'postperfusion syndrome' (Paloheimo et al, 1968). The early postnatal infections are also mainly asymptomatic, despite the continuing viruria, although some of the infants show transient disturbances of liver function and may suffer respiratory illnesses (Hanshaw, Betts, Simon, and Boynton, 1965; Stern, 1968). However, the full significance of these early chronic infections, particularly with regard to brain damage, awaits elucidation. The most important primary infection is that occurring in pregnancy because of the chance of foetal damage. Cytomegalovirus is the commonest known congenital infection and $0.5-1.0 \%$ of babies excrete the virus at birth (Stern, 1968; Hanshaw, Steinfeld, and White, 1968; Starr et al, 1970; Walker and Tobin, 1970). The consequences of congenital infection range from inapparent infection with viruria to fatal neonatal cytomegalic inclusion disease. The latter syndrome is fortunately rare. Most infected babies are either apparently healthy at birth or have only mild illnesses from which they soon recover. Nevertheless, some of them, as many as $10 \%$, are subsequently mentally retarded and microcephalic (Stern, Elek, Booth, and Fleck, 1969). Whether the reactivation of latent infection which occurs in pregnant women is ever clinically significant is uncertain. Foetal infection in successive pregnancies has been recorded (Embil, Oyere, and Haldane, 1970) but is most exceptional. However, infection on the cervix may indirectly contribute to abortion and miscarriage and to delayed development of the foetus (Levinsohn et al, 1969; Berenberg and Nankervis, 1970; Starr et al, 1970; Foy et al, 1970). The role of cytomegalovirus infection, whether primary or reactivation, in patients on immunosuppressive therapy and its influence on the course of the underlying disease has also proved remarkably difficult to evaluate, particularly as the cytomegalovirus is more often than not only one of several agents infecting the patient.

Cytomegalovirus, which until recently was largely unknown to most clinicians and mentioned by most textbooks only in small print, is, in fact, a widely distributed agent possessing a complex, and as yet largely undetermined, range of clinical activity. Even only as a preventable cause of mental deficiency it deserves much intensive study.

\section{References}

Alexander, E. E. (1967). Maternal and neonatal infection with cytomegalovirus in Taiwan. Pediat, Res., 1, 210.

Berenberg, W., and Nankervis, G. (1970). Long-term follow-up of cytomegalic inclusion disease of infancy. Pediatrics, 46, 403.

Carlström, G.(1965).Virologic studies on cy tomegalic inclusion disease. Acta paediat. scand., 54, 17-23.

Craighead, J. E. (1969). Immunologic response to cytomegalovirus infection in renal allograft recipients. Amer. J. Epidem., 90 506-513.

Craighead, J. E. (1971). Pulmonary cytomegalovirus infection in the adult. Amer. J. Path., 63, 487.

Diosi, P., Babusceac, L., Nevinglovschi, O., and Kun-Stoicu, G. (1967). Cytomegalovirus infection associated with pregnancy. Lancet, 2, 1063-1066.

Diosi, P., Moldovan, E., and Tomescu, N.'(1969). Latent cytomegalovirus infection in blood donors. Brit. med. J., 4, 660-662.

Duvall, C. P., Casazza, A. R., Grimley, P. M., Carbone, P. P. and Rowe, W. P. (1966). Recovery of cytomegalovirus from adults with neoplastic disease. Ann. intern. Med., 64, 531-541.

Embil, J. A., Ozere, R. L., and Haldane, E. V. (1970). Congenital cytomegalovirus infection in two siblings from consecutive pregnancies. J. Pediat., 77, 417-421.

Feldman, R. A. (1969). Cytomegalovirus infection during pregnancy: a prospective study and report of six cases. Amer. J. Dis. Child. $117,517-521$.

Foy, H. M., Kenny, G. E., Wentworth, B. B., Johnson, W. L., and Grayston, J. T. (1970). Isolation of Mycoplasma hominis, T strains, and cytomegalovirus from the cervix of pregnan women. Amer. J. Obstet. Gynec., 106, 635-643.

Glasgow, L. A., Hanshaw, J. B., Merigan, T. C., and Petralli, J. K. (1967). Interferon and cytomegalovirus in vivo and in vitro. Proc. Soc. exp Biol. (N.Y.), 125, 843-849.

Hanshaw, J. B. (1966). Cytomegalovirus complement-fixing antibody in microcephaly. New Engl. J. Med., 275, 476-479.

Hanshaw, J. B., Betts, R. F., Simon, G., and Boynton, R. C. (1965). Acquired cytomegalovirus infection: association with hepatomegaly and abnormal liver function tests. New Engl. J. Med., 272, 602-609.

Hanshaw, J. B., Steinfeld, H. J., and White, C. J. (1968). Fluorescentantibody test for cytomegalovirus macroglobulin. New Engl. J. Med., 279, 566-570.

Harnden, D. G., Elsdale, T. R., Young, D. E., and Ross, A. (1967) The isolation of cytomegalovirus from peripheral blood. Blood, 30, 120-125.

Hildebrandt, R. J., Sever, J. L., Margileth, A. M., and Callagan, D. A. (1967). Cytomegalovirus in the normal pregnant woman. Amer. J. Obstet. Gynec., 98, 1125-1128.

Jack, I., and McAuliffe, K. C. (1968). Sero-epidemiological study of cytomegalovirus infections in Melbourne children and some adults. Med. J. Aust., 1, 206.209.

Kääriäinen, L., Klemola, E., and Paloheimo, J. (1966). Rise of cytomegalovirus antibodies in an infectious-mononucleosis-like syndrome after blood transfusion. Brit. med. J., 1, 1270-1272.

Kanich, R. E., and Craighead, J. E. (1966). Cytomegalovirus infection and cytomegalic inclusion disease in renal homotransplant recipients. Amer. J. Med., 40, 874-882.

King-Lewis, P. A., and Gardner, S. D. (1969). Congenital cytomegalic inclusion disease following intrauterine transfusion. Brit. med. J., 2, 603-605.

Klemola, E., von Essen, R., Wager, O., Haltia, K., Koivuniemi, A., and Salmi, I. (1969). Cytomegalovirus mononucleosis in previously healthy individuals: five new cases and follow-up of 13 previously published cases. Ann. intern. Med., 71, 11-19.

Krech, U., Jung, M., Bärlocher, K., and Sege, L. (1968). Investigation on the incidence of intrauterine cytomegalovirus infections. Germ. med. Mth., 13, 184-190.

Lang, D. J., Scolnick, E. M., and Willerson, J. T. (1968). Association of cytomegalovirus infection with the postperfusion syndrome. New Engl. J. Med., 278, 1147-1149.

Leinniki, P., Heinonen, K., and Pettay, O. (1971). High incidence of cytomegalovirus infections in early childhood. In Proceedings XIIth European Symposium of Poliomyelitis and Other Virus Diseases, Helsinki, 1971.

Levinsohn, E. M., Foy, H. M., Kenny, G. E., Wentworth, B. B., and Grayston, J. T. (1969). Isolation of cytomegalovirus from a cohort of 100 infants throughout the first year of life. Proc. Soc. exp. Biol. (N.Y.), 132, 957-962.

Luthardt, Th.,Siebert, H., Lösel, I., Quevedo, M., and Todt, R. (1971). Cytomegalievirus-infektionen bei Kindern mit Blutaustauschtransfusion im Neugeborenenalter. Klin. Wschr., 49, 81-86.

McCracken, G. H., Jr., Shinefield, H. R., Cobb, K., Rausen, A. R. Dische, M. R., and Eichenwald, H. F. (1969). Congenita cytomegalic inclusion disease: a longitudinal study of 20 patients. Amer. J. Dis. Child., 117, 522-539.

Medearis, D. N., Jr. (1964). Observations concerning human cytomegalovirus infection and disease. Johns Hopk. Hosp. Bull., $114,181-211$ 
Mendez-Cashion, D., Valcarcel, M. I., Ramirez de, Arellano, R. and Rowe, W. P. (1963). Salivary gland virus antibodies in Puerto Rico. Bol. Asoc. méd. P. Rico., 55 447-455.

Murray-Lyon, I. M., Evans, D. B., Foster, W. D., Holden, R. J., Rake, M. O., Stern, H., Calne, R. Y., and Williams, R. (1970). Liver transplantation in man: the significance, patterns, and control of infection. Brit. J. Surg., 57, 280-284.

Numazaki, Y., Yano, N., Morizuka, T., Takai, S., and Ishida, N. (1970). Primary infection with human cytomegalovirus: virus isolation from healthy infants and pregnant women. Amer. J. Epidem., 91, 410-417.

Olson, L. C., Ketusinha, R., Mansuwan, P., and Snitbhan, R. (1970). Respiratory tract excretion of cy tomegalovirus in Thai children. J. Pediat., 77, 499-504.

Osborn, J. E., and Medearis, D. N., Jr. (1966). Studies of relationship between mouse cytomegalovirus and interferon. Proc. Soc. exp. Biol. (N.Y.), 121, 819-824.

Paloheimo, J. A., von Essen, R., Klemola, E., Kääriäinen, L. and Siltanen, P. (1968). Subclinical cytomegalovirus infections and cytomegalovirus mononucleosis after open hear surgery. Amer. J. Cardiol., 22, 624-630.

Prince, A. M., Szmuness, W., Millian, S. J., and David, D. S. (1971). A serologic study of cytomegalovirus infections associated with blood transfusions. New. Engl. J. Med., 284, 1125-1131.

Rowe, W. P., Hartley, J. W., Waterman, S., Turner, H. C., and Huebner, R. J. (1956). Cytopathogenic agent resembling human salivary gland virus recovered from tissue cultures of human adenoids. Proc. Soc. exp. Biol. (N.Y.), 92, 418-424.

Shinefield, H. R., and Eichenwald, H. F. (1968). Discussion. In Proceedings of Conference on Prevention of Mental Retardation Through Control of Infectious Diseases, 1966 (Public Health Service Publ. No. 1692), edited by H. F. Eichenwald p. 65 U.S. Govt. Ptg. Office, Washington, D.C.

Starr, J. G., Bart, R. D., Jr., and Gold, E. (1970). Inapparent congenital cytomegalovirus infection: clinical and epidemiologic characteristics in early infancy. New Engl. J. Med., 282, 1075 1078.

Stern, H. (1968). Isolation of cytomegalovirus and clinical manifestations of infection at different ages. Brit. med. J., 1, 665-669.

Stern, H. (1971). Cytomegalovirus and mental deficiency. In Proceedings of the XIIth International Congress of Pediatrics, Vienna, vol. 6, p. 301 .

Stern, H., and Elek, S. D. (1965). The incidence of infection with cytomegalovirus in a normal population. A serologicalstudy in Greater London. J. Hyg. (Lond.), 63, 79-87.

Stern, H., Elek, S. D., Booth, J. C., and Fleck, D. G. (1969). Microbial causes of mentralretardation : the role of prenatalinfections with cytomegalovirus, rubella virus and toxoplasma. Lancet, 2, 443-448.

Stevens, D. P., Barker, L. F., Ketcham, A. S., and Meyer, H. M., Jr. (1970). Asymptomaticcytomegalovirus infection following blood transfusion in tumor surgery. J. Amer. med. Ass., 211, 1341 1344.

Stulberg, C. S., Zuelzer, W. W., Page, R.H., Taylor, P. E., and Brough, A. J. (1966). Cytomegalovirus infections with reference to isolations from lymph nodes and blood. Proc. Soc. exp. Biol. (N.Y.), 123, 976-982.

Sullivan, M. P., Hanshaw, J. B., Cangir, A., and Butler, J. J. (1968). Cytomegalovirus complement-fixation antibody levels of leukemic children: results of a longitudinal study. J. Amer. med. Ass., 206, 569-574.

Ten Bensel, R. W. and St. Geme, J. W., Jr. (1968). A search for a reservoir of cytomegalovirus in salivary gland tissue. J. Pediat. 72, 479.482.

Walker, G. H., and Tobin, J. O'H. (1970). Collaborative study: cytomegalovirus infection in the North West of England: a report on a two-year study. Arch. Dis. Childh., 45, 513.

Weller, T. H., and Hanshaw, J. B. (1962). Virologic and clinical observations on cytomegalic inclusion disease. New Engl. J. Med., 266, 1233-1244. 